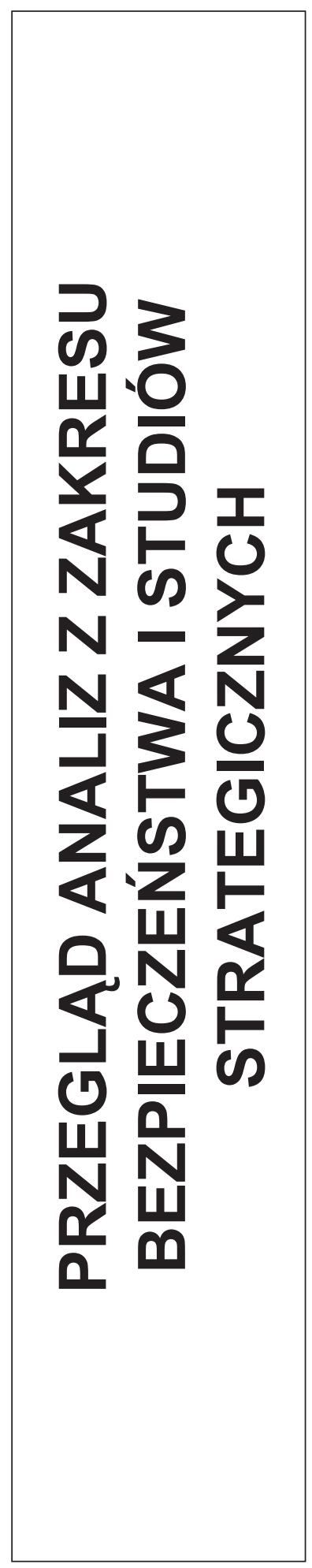





\section{POLSKIE ANALIZY STRATEGICZNE - PRZEGLĄD 2014 ROKU}

Celem niniejszego artykułu jest zaprezentowanie stanu badań nad bezpieczeństwem międzynarodowym w Polsce przez pryzmat artykułów publikowanych w czołowych czasopismach naukowych tej dyscypliny w 2014 r. Siłą rzeczy przegląd ten ma charakter selektywny i opiera się na subiektywnym doborze omawianych tekstów dokonanym przez autora. Z uwagi na ograniczenia czasoprzestrzenne skupiono się na czterech periodykach z obszaru stosunków międzynarodowych oraz studiów nad bezpieczeństwem. Są to: „Kwartalnik Bellona”, „Bezpieczeństwo Narodowe”, „Rocznik Strategiczny” oraz „Stosunki Międzynarodowe”.

Rok 2014 obfitował w znaczace wydarzenia kształtujące (a niejednokrotnie wręcz redefiniujące) międzynarodowe środowisko bezpieczeństwa, tak na poziomie ładu globalnego, jak również w odniesieniu do szeregu regionalnych kompleksów bezpieczeństwa. Dość wspomnieć (tytułem zasygnalizowania) takie kwestie, jak: przekształcenie ostrego kryzysu polityczno-militarnego dotykającego Ukrainę w otwartą (i umiędzynarodowiona) wojnę domową; postępującą destabilizację bliskowschodniego kompleksu niestabilności objawiającą się ekspansją terytorialną radykalnej organizacji islamistycznej określającej się mianem „Państwa Islamskiego”; zakończenie zasadniczej operacji stabilizacyjnej NATO w Afganistanie czy (,last but not least”) utrzymywanie stanu napięcia w stosunkach między czołowymi potęgami regionu Azji i Pacyfiku stanowiącego kontekst dla coraz śmielszych inicjatyw przebudowy regionalnej architektury współpracy gospodarczej i bezpieczeństwa podejmowanych przez Chińską Republikę Ludową.

Zarysowany powyżej „duch czasu” znalazł odbicie w zainteresowaniach polskich badaczy. Na łamach będących przedmiotem przeglądu periodyków często gościła tematyka przyszłości NATO oraz Wspólnej Polityki Bezpieczeństwa i Obrony Unii Europejskiej, uwarunkowań konfliktu ukraińskiego oraz bezpieczeństwa energetycznego. Autorzy poruszali również takie zagadnienia, jak zmiany w globalnym układzie sił, problemy bezpieczeństwa międzynarodowego w regionach Bliskiego Wschodu oraz Azji i Pacyfiku czy przyszłość sił zbrojnych mocarstw. W ramach niniejszego przeglądu zostaną zaprezentowane najciekawsze (w opinii jego autora) teksty odnoszące się do tak zarysowanych obszarów tematycznych.

Z punktu widzenia polskiej polityki bezpieczeństwa, najistotniejszym problemem bezpieczeństwa międzynarodowego w 2014 r. był narastający konflikt polityczno-militarny w Ukrainie, który latem tego roku przekształcił się w otwartą wojnę domową, przy bezpośrednim zaangażowaniu militarnym Federacji Rosyjskiej. W sposób naturalny krajowe środowiska naukowe zgłębiające problematykę bezpieczeństwa między- 
narodowego podjęły się analizy źródeł i uwarunkowań tego konfliktu, jak również przedstawiły prognozy jego dalszej ewolucji. Dobrą ilustrację tego trendu stanowią artykuły autorstwa Ryszarda Zięby (Międzynarodowe implikacje kryzysu ukraińskiego) oraz Andrzeja Makowskiego (O co my walczymy?). Obaj autorzy jako podstawę swych rozważań przyjmują perspektywę realizmu politycznego, podkreślając tym samym, iż istotą konfliktu jest rywalizacja mocarstw o wpływy na obszarze poradzieckim. W konsekwencji, źródeł kryzysu polityczno-militarnego, który ogarnął Ukrainę jesienią $2013 \mathrm{r}$. upatrują w zderzeniu ambicji Zachodu (Stanów Zjednoczonych i Unii Europejskiej) do włączenia tego państwa we własne struktury integracyjne z rosyjską ambicją utrzymania swej uprzywilejowanej pozycji w przestrzeni poradzieckiej.

Warto odnotować, iż obaj autorzy nieco inaczej rozkładają akcenty w swych ocenach przyczyn konfliktu. Ryszard Zięba podkreśla przede wszystkim nieodpowiedzialną (w jego opinii) politykę Zachodu (w tym Polski) obliczoną na wciągnięcie Ukrainy w orbitę własnych wpływów kosztem interesów Rosji. Stawia chociażby następujące pytania: „Czymże w takim ujęciu jest intensywne wspieranie prozachodnich aspiracji politycznie rozdartej Ukrainy? Czy nie jest to demokratyczny (liberalny) mesjanizm, pomieszany z republikańskim (realistycznym) dążeniem do ekspansji? Stowarzyszenie się Ukrainy z Unią Europejską, a w przyszłości przystąpienie do Unii, jest traktowane jako uzysk dla Zachodu kosztem Rosji?" (Zięba, 2014: 16). Z kolei Andrzej Makowski, przyznając, iż Zachód „przekroczył rosyjskie czerwone linie” zwraca jednak większą uwagę na trwałe cechy rosyjskiej polityki zagranicznej (mesjanizm i imperializm obronny) oraz jej uwarunkowania wewnętrzne (charyzmatyczna legitymizacja władzy). W konsekwencji realizowana jest wizja ,[...] Rosji jako gwaranta praw i obrońcy ludności rosyjskojęzycznej za granicą oraz specyficznie pojmowanego dobrosąsiedztwa, a tak naprawdę ograniczonej suwerenności, jako warunku uznawania przez Moskwę niepodległości i integralności terytorialnej państw poradzieckich" (Makowski, 2014: 45). Na bazie tych ocen można pokusić się o wniosek, iż mimo niezaprzeczalnej użyteczności perspektywy realistycznej, pełniejsza analiza konfliktu ukraińskiego powinna uwzględniać także perspektywę liberalną (rywalizacja różnych wzorców ustrojowych), jak również konstruktywistyczną (uwzględniającą kwestie tożsamości i kultury strategicznej zaangażowanych państw i narodów).

Odnosząc się do konsekwencji konfliktu ukraińskiego, tak dla regionu, jak i globalnego porządku międzynarodowego, obaj badacze podkreślają, iż zwiastuje on powrót do szerokiego stosowania przez mocarstwa klasycznej realpolitik opartej na sile. Mimo iż tendencja ta nie jest wyłączną domeną Federacji Rosyjskiej (a pewnym precedensem, mimo istotnych różnic, dla aneksji Krymu i interwencji zbrojnej we wschodniej Ukrainie stanowiły działania Zachodu wobec chociażby Kosowa i Libii) to jak zauważa A. Makowski: „,...] Kreml pokazał, że jest gotowy do użycia siły, gdy uzna to za konieczne, a Zachód dowiódł, że do czegoś takiego zdolny nie jest. To tworzy asymetryczną relację, w której zdecydowana Rosja może spodziewać się uzyskania niemal wszystkiego, co chce osiągnąć" (Makowski, 2014: 43). W takiej sytuacji autorzy omawianych tekstów podpowiadają, iż droga do rozwiązania konfliktu wiedzie przez negocjacje mocarstw i wypracowanie kompromisowego rozwiązania czyniącego Ukrainę państwem neutralnym i swoistym pomostem między Zachodem a Rosją. 
R. Zięba przytacza opinie znaczących obserwatorów amerykańskich i zachodnioeuropejskich (Henry'ego Kissingera, Zbigniewa Brzezieńskiego, Jacka Matlocka oraz Güntera Verheugena), które można sprowadzić do postulatu „finlandyzacji” Ukrainy. Miałoby to pozwolić z jednej strony zachować suwerenność tego państwa, a z drugiej uspokoić obawy rosyjskie. Uznając atrakcyjność takiego postulatu z punktu widzenia dążenia do pokoju i stabilizacji w Europie, warto zwrócić uwagę na istotne różnice między sytuacją Finlandii w trakcie zimnej wojny a tą w jakiej obecnie znajduje się Ukraina, które czynią takie analogie co najmniej problematycznymi. Po pierwsze, w chwili zawierania traktatu pokojowego z Finlandia, ZSRR nie prowadził działań wojennych na terytorium tego państwa z użyciem własnych sił zbrojnych, czy też za pomocą uzbrajanych, szkolonych i sterowanych przez siebie zbrojnych grup separatystycznych. Po drugie, Finlandia miała ograniczoną swobodę prowadzenia polityki zagranicznej i bezpieczeństwa, ale kwestie polityki wewnętrznej rozstrzygano w Helsinkach. Tymczasem obserwując przebieg wydarzeń ostatniego roku można prognozować, iż Rosji może nie zadowolić tak pojęta „finlandyzacja” Ukrainy. Obecne władze Federacji Rosyjskiej zdają się oczekiwać trwałego powiązania polityki wewnętrznej i zewnętrznej tego państwa z Rosją w sposób, który przywodzi na myśl neokolonialną politykę Françafrique analizowaną przez Ivana Krivoushina na łamach czasopisma „R/evolutions: Global Trends \& Regional Issues" (Krivoushin, 2014). Po trzecie w końcu, Związek Radziecki nie postrzegał Finlandii jako części „ziem Ruskich” zajmującej szczególne miejsce $\mathrm{w}$ rosyjskiej pamięci zbiorowej.

A. Makowski dochodzi do podobnych wniosków, pytając: „,czy Rosja ma prawo do samodzielnej polityki i określania swoich stref wpływów. Jeśli spojrzeć na historię Rosji i Zachodu, to nie sposób nie odpowiedzieć twierdząco" (Makowski, 2014: 48). Nie ulega wątpliwości, iż tak jak zauważają obaj autorzy, Rosja jest trwałym biegunem regionalnego i globalnego układu sił, a zatem w dłuższej perspektywie czasowej Zachód będzie prawdopodobnie musiał znaleźć sposób na ułożenie relacji z tym państwem na nowo. R. Zięba zauważa, iż zarówno dla USA, jak i dla państw UE współpraca Rosji może okazać się przydatna przy podejmowaniu wyzwań związanych z ekspansją islamskiego ekstremizmu, czy wobec zmiany globalnego układu sił na korzyść wschodzących potęg (symbolizowanych chociażby przez grupę BRICS). Pogląd ten był również konsekwentnie promowany przez Zbigniewa Brzezińskiego, który zarówno w „Wielkiej Szachownicy”, jak i w „Strategicznej Wizji” namawiał do „włączenia Rosji do Zachodu". Takie oceny zdają się być w pewnych punktach zbieżne z tezą Samuela Huntingtona o zderzeniu cywilizacji, która jednak budzi istotne kontrowersje. Rozważając rekomendacje dla polityki płynące z tych analiz warto zauważyć, iż akceptacja rosyjskiej strefy wpływów jest logicznym rozwiązaniem dla państw takich jak USA, Francja, Wielka Brytania czy Niemcy, tj. de facto mocarstw, które mają pozycję i potencjał, z którymi Rosja się liczy. Natomiast dla państwa takiego jak Polska, które jeszcze niedawno znajdowało się w strefie wpływów Moskwy, akceptacja polityki, która de facto odrzuca konsekwencje rozpadu ZSRR i ogranicza podmiotowość państw leżących na obszarze „bliskiej zagranicy” jest rozwiązaniem znacznie bardziej ryzykownym.

Rok 2014 był bez wątpienia przełomowy dla Sojuszu Północnoatlantyckiego. Wobec zakończenia zasadniczej misji stabilizacyjnej ISAF w Afganistanie powróciło zna- 
ne z początku lat dziewięćdziesiątych XX w. pytanie: „czemu ma służyć NATO?” Na łamach polskiej prasy naukowej toczyła się na ten temat ożywiona debata. Najważniejsze z przewijających się $\mathrm{w}$ jej trakcie problemów zostały trafnie zarysowane przez Marka Madeja w tekście pt. NATO: zagończyk wraca do pracy u podstaw zamieszczonym w „Roczniku Strategicznym”. Artykuł ten jest zasadniczo podsumowaniem aktywności Sojuszu w 2013 r., zawiera jednak istotną i celną analizę kierunku, w którym zmierzała w tym okresie ewolucja Organizacji. Jak zauważa M. Madej, NATO znajdowało się $\mathrm{w}$ fazie przejściowej między okresem aktywnego zaangażowania operacyjnego (przede wszystkim w Afganistanie) a „fazą preparacyjną”, w ramach której miano doskonalić gotowość do działania. Autor stawia zdecydowaną diagnozę o ,zwrocie introwertycznym" Sojuszu przejawiającym się niechęcią państw członkowskich do zaangażowania w kolejne znaczące operacje ekspedycyjne i skupienie się na budowie zdolności wojskowych za pomocą takich inicjatyw jak Smart Defence (SD) czy Connected Forces Initiative (CFI). W opinii M. Madeja niechęć do podejmowania kolejnych zobowiązań operacyjnych wynika z trzech zasadniczych przesłanek: efektów kryzysu ekonomicznego (przede wszystkim cięć budżetów obronnych państw członkowskich), zmiany polityki USA (zwrot ku Azji i Pacyfikowi) oraz dotychczasowych doświadczeń operacyjnych (a konkretnie braku wymiernych efektów operacji Afgańskiej). Autor omawianego tekstu jest jednoznacznie krytyczny w ocenie efektywności wieloletnich wysiłków dowodzonych przez NATO sił międzynarodowych podejmowanych na rzecz stabilizacji Afganistanu. Nie pada co prawda słowo „porażka”, ale diagnoza jest jasna: brak wyraźnego sukcesu zdecydowanie zniechęca sojuszników do podejmowania podobnych operacji w przyszłości.

W tej sytuacji istotne staje się pytanie: wypełnianie jakich zadań stanie się zasadniczą treścią aktywności sojuszu w sytuacji „wycieńczenia” operacjami out of area? M. Madej zauważa, iż w 2013 roku w codziennej działalności NATO duży nacisk położono na szeroko reklamowane inicjatywy SD i CFI, które mają pozwolić na zachowanie pożądanych zdolności wojskowych w warunkach cięć budżetowych i braku stałej aktywności operacyjnej. W opinii autora omawianego artykułu w rzeczywistości programy te sprowadzają się do mało ambitnych projektów służących konserwacji już posiadanych i raczej skromnych zdolności i zdają się być napędzane raczej instytucjonalną inercją niż jasną wizją strategiczną. Nie sposób nie zauważyć, iż rozwój/utrzymanie zdolności wojskowych jest istotnym elementem strategii obronnej każdego państwa i sojuszu. Jednak sam w sobie takiej strategii nie stanowi. Jest raczej ostatnim etapem $\mathrm{w}$ łańcuchu $\mathrm{w}$ uproszczeniu złożonym także $\mathrm{z}$ wyznaczenia strategicznych celów oraz określenia sposobów ich realizacji. Wobec tego jakie cele i zadania stawiaja przed NATO państwa członkowskie w okresie przejściowym? M. Madej ocenia, że będzie to raczej kolektywna obrona, zaznacza jednak, że będzie ona prawdopodobnie rozumiana inaczej niż w czasach zimnej wojny. Zwraca on uwagę, iż dla wielu sojuszników priorytetowa jest ochrona przed zagrożeniami nietradycyjnymi (takimi jak terroryzm, cyberzagrożenia czy proliferacja BMR). Biorąc pod uwagę, iż zbiorowa obrona przed nimi może wymagać działań ekspedycyjnych prognozuje on, iż w przyszłości granice między tradycyjnie rozumianą obroną kolektywną a misjami out of area będą się zacierały. M. Madej identyfikuje również trafnie zasadnicze wyzwania, które będą utrudniały wypracowanie spójnej wizji strategicznej sojuszu na okres po 2014 r. 
oraz jej realizację. Są to: kryzys ekonomiczny, wycieńczenie nieskutecznymi operacjami, a także podziały wśród sojuszników i brak energicznego przywództwa. Trafne podsumowanie przeprowadzonej w tekście analizy stanowi stwierdzenie, iż sojusznicy chca, aby NATO „było przede wszystkim silne, zwarte, gotowe. Nie uzgodnili jednak jeszcze jak bardzo i na co" (Madej, 2014: 84).

Dość jednoznaczną odpowiedź na to pytanie proponuje Andrew Michta w opublikowanym na łamach „Bezpieczeństwa Narodowego” artykule pt. NATO po 2014 roku - jakie priorytety? Punktem wyjścia dla tej analizy jest diagnoza zasadniczych zmian w międzynarodowym środowisku bezpieczeństwa, które będą kształtowały przyszłe wyzwania dla Sojuszu. Zdaniem A. Michty są to: zmiana układu sił w regionie Azji i Pacyfiku (przede wszystkim rosnąca rywalizacja Amerykańsko-Chińska), eskalacja niestabilności na Bliskim Wschodzie oraz asertywna polityka Rosji w Europie Wschodniej. Dodatkowo autor ten podkreśla, iż poważną słabością NATO są zaniedbania w sferze hard security. Wynikają one z głębokich cięć wydatków obronnych w państwach członkowskich prowadzących do „demilitaryzacji Europy” oraz istotnego ograniczenia długofalowego potencjału USA. W opinii A. Michty w obliczu takich uwarunkowań NATO musi przede wszystkim zmierzyć się z trzema wyzwaniami: określeniem skali i zakresu globalnego zaangażowania, wypracowaniem polityki wobec Rosji w obliczu jej coraz bardziej asertywnego zachowania oraz (kluczowym według niego) określeniem charakteru relacji transatlantyckich. Dla autora omawianego tekstu nie ulega wątpliwości, iż w sytuacji gdy „uwarunkowania regionalne i globalne NATO łączą się w jedną całość nie tylko w kwestii obronności i bezpieczeństwa, ale w coraz większym stopniu także w wymiarze politycznym" (Michta, 2014: 121) kluczową kwestią dla przyszłości NATO jest utrzymanie zdolności do globalnego działania. Ciekawa jest zaprezentowana przez tego autora ocena efektów misji afgańskiej. A. Michta uznaje ją za sukces, zwracając przede wszystkim uwagę na to, iż wykazała ona zdolność Europejskich sojuszników do efektywnych działań koalicyjnych (w co powątpiewano od czasu operacji bałkańskich). Nie sposób jednak nie zauważyć, iż w artykule tym wyraźnie widoczna jest amerykańska perspektywa odnośnie przyszłości NATO. Można powiedzieć, iż ISAF ocenia się tutaj jako sukces przede wszystkim z uwagi na to, iż Sojusz potwierdził swą użyteczność dla polityki bezpieczeństwa USA. Silne podkreślanie konieczności zachowania przez NATO zdolności do działania w wymiarze globalnym (w tym na obszarze Azji i Pacyfiku) można interpretować jako postrzeganie Sojuszu jako swoistego „globalnego asystenta USA”. Takie podejście wynika wprost z trudnej do podważenia diagnozy, iż sednem NATO jest więź transatlantycka. Faktycznie, Europejscy sojusznicy przyzwyczaili się do hojnego czerpania $\mathrm{z}$ amerykańskich gwarancji bezpieczeństwa. W tym kontekście niezwykle istotna jest ocena A. Michty, iż w wyniku kryzysu gospodarczego zasoby USA są o wiele bardziej ograniczone niż kiedykolwiek wcześniej w historii NATO.

Pewien kontrapunkt dla prezentowanej przez A. Michtę wizji globalnego zaangażowania NATO stanowi polskie stanowisko odnośnie przyszłości Sojuszu przedstawione przez Stanisława Kozieja i Pawła Pietrzaka w artykule Szczyt NATO w Walii: uwarunkowania, rezultaty, wnioski dla Polski, który również można znaleźć na łamach periodyku Biura Bezpieczeństwa Narodowego. Obaj autorzy byli członkami polskiej delegacji na Szczyt NATO w Newport, który odbył się we wrześniu 2014 r. Omawiany 
artykuł ma częściowo charakter relacji z obrad oraz podsumowania zasadniczych ustaleń zawartych w deklaracji końcowej. W obliczu rosyjskiej agresji wobec Ukrainy stanowisko Polski (które uzyskało wsparcie innych państw członkowskich z Europy Środkowej i Wschodniej) jednoznacznie podkreślało konieczność skupienia wysiłków sojuszniczych na funkcji zbiorowej obrony obszaru traktatowego. Przedstawiciele BBN zwracają uwagę na wyzwania związane z zarysowaniem się wśród Sojuszników wyraźnego podziału geopolitycznego wobec oceny najpoważniejszych zagrożeń dla wspólnego bezpieczeństwa. Państwa flanki wschodniej obawiają się przede wszystkim agresywnych poczynań Rosji, podczas gdy zasadniczym źródłem niepokoju dla Europy Południowej jest rozwój tzw. Państwa Islamskiego. Stan ten prowadzi do swoistej sytuacji rywalizacji dwóch geopolitycznych osi zaangażowania NATO o szczupłe w sumie zasoby Sojuszu.

Odnosząc się do konkluzji szczytu w Newport S. Koziej i P. Pietrzak prezentują listę inicjatyw, które powinny zostać podjęte przez Polskę dla wzmocnienia narodowego i sojuszniczego systemu bezpieczeństwa obliczonego na skontrowanie rosyjskiej strategii agresji podprogowej. Są one zasadniczo pochodną założeń tzw. „doktryny Komorowskiego" opisanej przez Mariusza Fryca w artykule Doktryna Komorowskiego - próba scharakteryzowania. Idea, zakres, priorytety, realizacja (również „Bezpieczeństwo Narodowe"). Cztery zasadnicze filary nowej doktryny to: przeniesienie punktu ciężkości z misji ekspedycyjnych na bezpieczeństwo i obronę własnego terytorium, uznanie narodowego potencjału bezpieczeństwa za rdzeń i gwarancję bezpieczeństwa narodowego, rozwój „zdolności przeciwzaskoczeniowych” (czyli zapewniających „możliwość obrony i ochrony społeczeństwa, a także infrastruktury krytycznej przed zagrożeniami militarnymi powstałymi $\mathrm{w}$ sytuacjach politycznie niejasnych czy też trudno-konsensusowych") oraz umacnianie podmiotowości strategicznej Polski przez udział w organizacjach międzynarodowych i kształtowanie ich stosownie do własnych interesów strategicznych (Fryc, 2014: 48).

Próba podsumowania rozważań zawartych w omówionych powyżej artykułach może prowadzić do wniosku, iż gwałtowne przeobrażenia w międzynarodowym środowisku bezpieczeństwa (związane z wojną ukraińską oraz ekspansją tzw. Państwa Islamskiego) stanowią wyraźny impuls określający rolę i użyteczność NATO właśnie w momencie, gdy zakończenie misji afgańskiej zasiało niepewność co do przyszłości tej organizacji. Można zatem powiedzieć, iż rozwijające się u granic wspólnoty transatlantyckiej konflikty w zasadzie umocniły pozycję NATO jako czołowej organizacji bezpieczeństwa tego obszaru. Można nawet pokusić się o diagnozę, iż obecnie sojusznicy stoją przed najpoważniejszymi zagrożeniami dla swego bezpieczeństwa od zakończenia zimnej wojny. Może to być czynnik, który przywróci solidarność sojuszniczą i determinację do rozwoju potencjału wspólnej obrony. Warto jednak zauważyć, iż w przeciwieństwie do lat zimnej wojny NATO nie stoi wobec jednego wspólnego dla wszystkich zagrożenia. Tym razem niebezpieczeństwo zdaje się nadciągnąć z dwóch odmiennych i geograficznie odległych wektorów. Stwarza to nowe wyzwania dla budowy wspólnej polityki bezpieczeństwa Sojuszu.

Poważne pytania o przyszłość stawiano na łamach omawianych periodyków nie tylko w odniesieniu do NATO, ale również Wspólnej Polityki Bezpieczeństwa i Obrony Unii Europejskiej. Ten obszar integracji europejskiej jest traktowany jako istotna deter- 
minanta szerszej architektury bezpieczeństwa europejskiego (co znajduje chociażby odzwierciedlenie w zapisach Strategii Bezpieczeństwa Narodowego RP z 2014 r.). Można jednak zaryzykować twierdzenie, iż w 2014 r. problem przyszłej roli WPBiO stwarzał większe wyzwania niż analogiczne wątpliwości dotyczące NATO. Dokonując przeglądu sytuacji w tej dziedzinie na łamach „Rocznika Strategicznego” Marcin Terlikowski i Marek Madej (Wspólna Polityka Bezpieczeństwa i Obrony UE - przetom, którego (zgodnie z planem) nie byto) przedstawili dość pesymistyczną diagnozę sytuacji. Przede wszystkim podkreślono, iż nadzieje, iż szczyt Rady Europejskiej poświęcony problemom WPBiO (z grudnia 2013 r.) wytyczy strategiczny kierunek jej dalszego rozwoju i stanie się impulsem dla pogłębiania współpracy, okazały się płonne. W opinii tych autorów zasadniczym problemem jest sprowadzenie WPBiO do szeregu ograniczonych i luźno ze sobą powiązanych inicjatyw i programów (często o charakterze technicznym), które nie tworzą istotnej „strategicznej wartości dodanej”. Obserwując wysiłki na rzecz rozwoju zdolności wojskowych, próby budowania wspólnej polityki odnośnie bazy przemysłowo-obronnej czy ograniczony geograficznie i przedmiotowo zakres operacji prowadzonych pod sztandarami UE można dojść do wniosku, iż motorem kontynuacji tych inicjatyw jest bardziej siła instytucjonalnej inercji bądź dążenie poszczególnych państw członkowskich do realizacji narodowych interesów za pomocą instrumentów unijnych (widoczne szczególnie w przypadku zaangażowania operacyjnego w Afryce, mocno skorelowanego z priorytetami polityki bezpieczeństwa Francji) niż jasna wizja strategiczna wspólnych działań na rzecz bezpieczeństwa Wspólnoty.

Autorzy omawianego artykułu głównych źródeł tego swoistego marazmu upatrują w kryzysie gospodarczym oraz braku przywództwa. Zdaje się, iż drugi czynnik ma tutaj znaczenie rozstrzygające. Jak zauważają M. Terlikowski i M. Madej, w Europie doszło do proliferacji inicjatyw (sub)regionalnych w różnych konfiguracjach (np. współpraca brytyjsko-francuska, nordycka czy wyszehradzka), natomiast na poziomie całej Wspólnoty mamy raczej do czynienia z rozgrywaniem mniejszych i większych interesów narodowych. Jest to szczególnie widoczne w przypadku polityki wobec sektora przemysłowo-obronnego. W 2013 r. Komisja Europejska daż̇yła do ożywienia idei konsolidacji rynku zbrojeniowego Wspólnoty. Plany legislacyjne zostały jednak pogrzebane przez lobbing państw członkowskich na rzecz krajowego przemysłu obronnego. W tej dyskusji Polska stanęła po stronie tych, którzy opowiadali się za „zrównoważonym rozwojem" przemysłu obronnego w UE. W praktyce sprowadza się to do ochrony słabszych i mniej konkurencyjnych narodowych sektorów zbrojeniowych przed konkurencją i presją konsolidacyjna, które byłyby konsekwencją przyjęcia propozycji Komisji. Trudno się dziwić takiemu podejściu, biorąc pod uwagę, iż na konsolidacji tak rynku, jak i przemysłu skorzystałyby przede wszystkim czołowe koncerny zbrojeniowe z największych państw członkowskich. Autorzy ci zwracają też uwagę na ograniczony, często sektorowy i techniczny charakter operacji ekspedycyjnych prowadzonych w ramach WPBiO. Stawiają istotne pytanie o sens utrzymywania WPBiO jako osobnego instrumentu działań zewnętrznych UE, w sytuacji gdy większość operacji i tak ma charakter zintegrowany, często z niewielkim komponentem wojskowym.

W podobnym, dość pesymistycznym tonie utrzymana jest diagnoza Romana Kuźniara, zaprezentowana w artykule Wzlot i upadek Europejskiej Polityki Bezpieczeństwa i Obrony, zamieszczonym w „Bezpieczeństwie Narodowym”. Autor kreśli w nim krót- 
ką historię WPBiO z perspektywy jej „wzlotu” (zasadniczo pierwsza dekada XXI wie$\mathrm{ku}$ ) oraz „upadku” (który zbiegł się z początkiem szerszego kryzysu UE o charakterze finansowym i instytucjonalnym). Jak zauważa R. Kuźniar, na przełomie XX i XXI w. swoiste „prądy wznoszące” pogłębiającej się integracji oraz dążenia do uzyskania choćby częściowej samodzielności względem USA w obszarze bezpieczeństwa zapewniły pomyślny i obiecujący start WPBiO. W pierwszej dekadzie nowego wieku udało się przeprowadzić szereg ograniczonych, ale legalnych z prawnomiędzynarodowego punktu widzenia operacji (Bałkany, Afryka), które per saldo przyczyniły się do wzrostu bezpieczeństwa i stabilizacji w szerokim sąsiedztwie Wspólnoty. Działania te stanowiły jasny kontrast dla amerykańskiej interwencji w Iraku, która nie dość, że została przeprowadzona z pogwałceniem prawa międzynarodowego, to jeszcze w długofalowej perspektywie przyczyniła się raczej do destabilizacji Bliskiego Wschodu.

Autor omawianego artykułu zauważa, iż wojna przeciwko Irakowi z całą ostrością unaoczniła zasadniczą słabość szerszej unijnej polityki zagranicznej i bezpieczeństwa, która stała się przyczynąjej późniejszego kryzysu. Spory wokół zasadności interwencji zbrojnej i ostry podział między państwami członkowskimi na tym tle wyraźnie ukazały, „[...] łatwość, z jaką poszczególne kraje zdecydowały się działać unilateralnie, nie patrząc na interesy i stanowisko całej Unii, a tylko mając na względzie własne, dyktowane zewnętrznymi okolicznościami interesy" (Kuźniar, 2014: 39). R. Kuźniar zaznacza, iż upadek WPBiO rozpoczął się wraz z postępującym kryzysem strefy euro oraz ogólnym „wyhamowaniem” integracji europejskiej po fiasku Traktatu Konstytucyjnego. Zjawiska te mają jednak wspólny mianownik - wybicie się na pierwszy plan interesów (by nie powiedzieć egoizmów) narodowych. W zasadzie wszystkie najpoważniejsze „bolączki” wspólnej polityki w tym obszarze, jak niechęć do przyjęcia nowej Europejskiej Strategii Bezpieczeństwa, niewykorzystanie nowych narzędzi udostępnionych przez Traktat Lizboński (jak np. stałej współpracy strukturalnej) czy ograniczenie zaangażowania operacyjnego niemal wyłącznie do Afryki są pochodną forsowania przez państwa członkowskie swych własnych (często wąsko postrzeganych) interesów, co pozostawia bardzo ograniczoną przestrzeń dla prawdziwie „wspólnotowego” myślenia i działania. Problem ten szczególnie ostro objawił się w oblicz kryzysu Ukraińskiego. Jak zauważa R. Kuźniar: „Część państw opowiedziała się za stanowczą odpowiedzią na agresywną politykę Rosji (całościowymi sankcjami i pomocą dla Ukrainy), część ze względów biznesowo-gospodarczych stanęła de facto po stronie Rosji (przeciwko sankcjom i za kontynuacją »partnerskich « stosunków z tym krajem), a dla pozostałej części był to konflikt, który ich nie dotyczył” (Kuźniar, 2014: 44). Szczególnie mocno brzmi ocena, iż: „Niemałą rolę odegrało tu skorumpowanie rozległych elit polityczno-biznesowych w Europie Zachodniej przez umowny tandem Kreml-Gazprom" (Kuźniar, 2014: 44). Podsumowując swe rozważania, autor omawianego artykułu nie bez żalu konstatuje, iż budowa prawdziwie wiarygodnej polityki bezpieczeństwa i obrony UE będzie wymagała nowego pokolenia europejskich przywódców oraz kolejnej jakościowej przemiany struktur integracyjnych, do której najwyraźniej Wspólnota jeszcze nie dojrzałą. Podkreśla również, iż póki co wkład UE na rzecz bezpieczeństwa europejskiego sprowadza się głównie do jej funkcji jako wspólnoty bezpieczeństwa, która czyni konflikt zbrojny między jej członkami niemożliwym. 
Próbując podsumować pesymistyczne oceny odnośnie kondycji i perspektyw WPBiO prezentowane przez wspomnianych wcześniej autorów można by postawić prowokacyjne pytanie: czy UE w ogóle potrzebuje ambitnej polityki bezpieczeństwa i obrony? Kolejne analizy ewidentnie wskazują, iż państwa członkowskie (poza sferą podniosłych deklaracji) traktująją w najlepszym razie jako mniej lub bardziej poręczny dodatek to narodowej polityki bezpieczeństwa względnie działań na forum NATO. Jeżeli taka jest wola państw członkowskich, to może rzeczywiście obrona zbiorowa i reagowanie na poważne kryzysy polityczno-militarne w bliższym i dalszym sąsiedztwie należałoby pozostawić NATO, a w ramach szerzej WPZiB ograniczyć się do tego co działa najlepiej, czyli zintegrowanego wsparcia cywilno-wojskowego (policyjnego?) na rzecz stabilizacji sytuacji pokonfliktowych?

W minionym roku uwaga polskich badaczy bezpieczeństwa międzynarodowego nie była skupiona wyłącznie na obszarze euroatlantyckim. Podjęto również ciekawe analizy istotnych przeobrażeń w ramach kluczowych z punktu widzenia ładu globalnego regionalnych kompleksów bezpieczeństwa - bliskowschodniego oraz azjatycko-pacyficznego. W opublikowanym na łamach „Bezpieczeństwa Narodowego” artykule pt. Bliskowschodnia ,zimna wojna" czyli saudyjsko-irańska rywalizacja w regionie w obliczu , arabskiej wiosny”, Aleksandra Dzisiów-Szuszczykiewicz analizuje rywalizację dwóch kluczowych potęg regionalnych Bliskiego Wschodu. Jak trafnie zauważa autorka omawianego artykułu, rywalizacja saudyjsko-irańska nosi pewne znamiona zimnej wojny, ponieważ obejmuje rywalizację o religijne, polityczne i ekonomiczne przywództwo w regionie bez uwikłania w bezpośredni konflikt zbrojny, za to na drodze budowy sojuszy, propagandy oraz toczenia konfliktów zastępczych. Jednocześnie jednak trudno mówić o pełnej analogii z amerykańsko-sowiecką zimną wojną z uwagi na brak trwałych obozów sojuszniczych wokół głównych protagonistów oraz niewystępowanie polaryzacji dwubiegunowej w obliczu obecności innych niezależnych potęg regionalnych (Egipt, Turcja), a przede wszystkim wpływów supermocarstwa (USA).

Artykuł zawiera syntetyczne ujęcie podłoża rywalizacji saudyjsko-irańskiej, którą należy rozpatrywać na płaszczyźnie religijnej (oba państwa mają charakter wyznaniowy i reprezentują inne odłamy islamu), etniczno-narodowościowej (rywalizacja arabsko-perska) oraz czysto geopolitycznej (dążenie do przywództwa w regionie). Zasadniczo początków zimnej wojny między Rijadem a Teheranem należy szukać w skutkach rewolucji islamskiej w Iranie, która była wymierzona w tradycyjne porządki polityczne w tym regionie świata, zwiastowała przekształcenie Iranu w „eksportera rewolucji” oraz odwróciła relacje obu państw z USA (Iran z sojusznika Waszyngtonu stał się jego wrogiem). W opinii A. Dzisiów-Szuszczykiewicz rywalizacja saudyjsko-irańska wkroczyła w nową, ostrą fazę wraz z początkiem fali przemian politycznych w regionie znanych potocznie jako „Arabska Wiosna”. Dla Iranu niepokoje i przemiany polityczne stały się okazją do zwiększenia własnych wpływów w szeregu państw Bliskiego Wschodu. Rijad postrzegał to jako wielkie zagrożenie, zarówno dla legitymacji własnego ustroju, jak i regionalnej pozycji.

Autorka omawianego artykułu syntetycznie, ale jednocześnie kompleksowo przedstawia uwarunkowania i stan saudyjsko-irańskiej rywalizacji w szeregu państw regionu: Egipcie, Bahrajnie, Jemenie, Syrii, Libanie i Iraku. W konkluzjach zwraca ona 
jednak uwagę, iż dalsza eskalacja napięć i rywalizacji między oboma mocarstwami regionalnymi nie jest jedynym prawdopodobnym scenariuszem. Zwraca ona uwagę, iż w obu stolicach obecna jest świadomość, iż eskalacja konfliktu może przynieść istotne szkody, a korzyści może przynosić innym graczom (jak np. Turcja czy Katar). Stąd nie można wykluczyć prób wypracowania pewnego porozumienia. Ciekawy kontekst stanowi tu polityka regionalna USA, obliczona $\mathrm{w}$ ostatnim czasie na swoiste detente w stosunkach z Iranem. Pod wpływem analizy zaprezentowanej przez autorkę z Biura Bezpieczeństwa Narodowego nasuwają się dwie refleksje. Po pierwsze, wyraźna staje się rola konfliktu syryjskiego jako swoistego „punktu ciężkości” wydarzeń rozgrywających się w ramach bliskowschodniego regionalnego kompleksu bezpieczeństwa. Konflikt wewnętrzny w tym państwie stanowił istotną przesłankę nasilenia rywalizacji saudyjsko-irańskiej. Patrząc na takie kwestie jak ewolucja regionalnej polityki Turcji czy rozwój tzw. Państwa Islamskiego nie sposób przecenić znaczenia wydarzeń w Syrii dla całego regionu. Po drugie, obserwując skalę militarnego i finansowego zaangażowania Iranu w regionie będącego odpowiedzią na szanse i zagrożenia stawiane przez „Arabską Wiosnę” nie sposób nie postawić pytania o możliwość swoistego regional overstrech ze strony Teheranu. Jak długo państwo o niekorzystnej sytuacji gospodarczej będzie w stanie utrzymywać swoje zaangażowanie w tak wielu konfliktach?

W kontekście zmian zachodzących $\mathrm{w}$ regionalnym kompleksie bezpieczeństwa Azji i Pacyfiku na uwagę zasługuje artykuł Macieja Michałka pt. Przydatność kategorii systemu trybutarnego w analizie polityki zagranicznej Chin opublikowany w „Stosunkach Międzynarodowych”. Wzrost znaczenia Chińskiej Republiki Ludowej i jego konsekwencje dla ładu regionalnego są przedmiotem niezliczonych studiów i analiz dokonywanych przez badaczy na całym świecie. Artykuł M. Michałka skupia się na jednym $\mathrm{z}$ aspektów historycznego dziedzictwa tego regionu, który potencjalnie może znaleźć zastosowanie w analizie współczesnej sytuacji międzynarodowej. Przedmiotem rozważań jest system trybutarny jako kategoria analizy polityki zagranicznej ChRL i możliwego wpływu tej koncepcji na chińską wizję ładu regionalnego. Mianem systemu trybutarnego określa się pewien model stosunków między Cesarstwem Chińskim a państwami sąsiednimi, którego istotą było uznanie formalnej zwierzchności Chińskiego centrum, czego symbolicznym wymiarem było płacenie trybutu. System ten zasadniczo funkcjonował przez niemal 2000 lat aż do połowy XIX w. kiedy to mocarstwa kolonialne narzuciły dynastii Qing nierównoprawne traktaty. Szerokie zainteresowanie badaczy tym okresem historii Azji Wschodniej wynika w pierwszej kolejności z faktu, iż system trybutarny stanowił w wielu aspektach przeciwieństwo systemu westfalskiego, którego zasady, choć wykształciły się w XVII-wiecznej Europie, w zasadzie do dziś stanowią bazę systemu międzynarodowego. System trybutarny w samej swej istocie zakładał formalny brak równości między uczestniczącymi w nim podmiotami. Opierał się na dominacji i formalnym zwierzchnictwie Chin, które (zazwyczaj) było uznawane przez pozostałe podmioty. Badacze wskazują też często na mniejszą liczbę i skalę konfliktów zbrojnych w ramach tego systemu, zwłaszcza w porównaniu z intensywną rywalizacją państw narodowych tworzących system westfalski.

Rozważania te zapewne pozostałyby w polu badawczym historyków, gdyby nie fakt, iż dynamiczny wzrost potęgi ChRL na przestrzeni ostatnich trzech dekad i jego 
konsekwencje dla całego regionu Azji i Pacyfiku skłoniły niektórych badaczy do postawienia pytania o możliwość odtworzenia (przynajmniej częściowego) mechanizmów systemu trybutarnego we współczesnym ładzie regionalnym tego obszaru. Autor omawianego artykułu dokonuje kompleksowego przeglądu różnych stanowisk badawczych odnośnie miejsca koncepcji systemu trybutarnego w promowanej przez ChRL wizji ładu międzynarodowego. Przywołuje również szereg koncepcji prezentowanych przez chińskich przywódców jak np. „harmonijny świat” i „dyplomacja brzegowa”, które w pewnych aspektach można rozważać jako odwołanie do logiki systemu trybutarnego. Jak zauważa M. Michałek, dominacja Chin w ramach systemu trybutarnego opierała się na dwóch zasadniczych filarach: centralnej pozycji Chin w regionalnej gospodarce oraz atrakcyjności kulturowej Cesarstwa. Przy analizie współczesnych stosunków międzynarodowych na obszarze Azji i Pacyfiku najczęściej zwraca się uwagę na powrót Chin do roli centrum regionalnego sytemu gospodarczego. Faktycznie, gospodarka ChRL jest największa w całym regionie (i druga w świecie) i stanowi centrum zintegrowanych sieci produkcyjnych obejmujących cały Basen Zachodniego Pacyfiku. Pozostaje jednak wattpliwość czy ta dominacja na polu gospodarki przeniesie się na płaszczyznę polityczną.

M. Michałek stwierdza, iż najważniejszym celem polityki zagranicznej ChRL jest uzyskanie pozycji lidera Azji Wschodniej jako bazy dla wpływów na skalę globalną. Jednak osiagnięcie takiego statusu (np. przez odtworzenie sytemu trybutarnego) wymaga akceptacji ze strony pozostałych państw regionu. Sam autor zauważa, iż we współczesnych warunkach jest to co najmniej problematyczne. Soft power dzisiejszej ChRL nie jest nawet w przybliżeniu tak rozległa jak ta, którą rozporządzało Cesarstwo w czasach świetności systemu trybutarnego. Co więcej, Pekin musi się liczyć z obecnością i ambicjami innych ośrodków potęgi jak. np. Japonia czy Indie (nie wspominając nawet o wpływach USA). Szczególnie w ostatnich latach widać, iż konfrontacyjna polityka ChRL odnośnie sporów terytorialnych na Morzach Wschodnio- i Południowochińskim warunkuje wzrost poczucia zagrożenia i utratę zaufania wśród sąsiadów. Wszystkie te czynniki sprawiają iż kategoria systemu trybutarnego stanowi interesujące i przydatne, ale często również przeceniane, narzędzie analizy chińskiej polityki zagranicznej. Warto jednak zwrócić uwagę, iż ostatnie inicjatywy Pekinu zmierzają de facto $\mathrm{w}$ stronę budowy alternatywnej architektury integracji regionalnej w Azji Wschodniej tak w wymiarze gospodarczym (chociażby inicjatywy Nowego Szlaku Jedwabnego czy Azjatyckiego Banku Inwestycji Infrastrukturalnych), jak i bezpieczeństwa (wzmacnianie Konferencji w sprawie Interakcji i Środków Budowy Zaufania w Azji). Być może kategoria systemu trybutarnego może być użyteczna dla analizy tych procesów.

Obok analizy stanu i perspektyw międzynarodowego środowiska bezpieczeństwa w poszczególnych regionach, na łamach omawianych periodyków pojawiały się również refleksje o szerszej perspektywie przestrzennej i czasowej. Na uwagę niewątpliwie zasługuje zamieszczony w „Roczniku Strategicznym” artykuł Mirosława Sułka pt. USA, UE i Chiny - trzy bieguny w globalnym uktadzie sit. Autor ten jest uznanym badaczem zagadnień pomiaru potęgi państw. Silna podstawa metodologiczna i merytoryczna jest widoczna w omawianej analizie. Wychodząc z założenia, iż ład światowy znajduje się obecnie w okresie przyspieszenia zmiany układu sił, autor omawianego ar- 
tykułu decyduje się na kompleksową analizę potęgi trzech podmiotów: USA, Unii Europejskiej oraz Chińskiej Republiki Ludowej. Wybór ten uzasadnia argumentem, iż są to obecnie największe jednostki polityczne świata pod względem gospodarczym i demograficznym. W toku wywodu podejmuje próbę odpowiedzi na pytanie czy są również nimi pod względem militarnym i politycznym. Naturalnie dobór analizowanych przedmiotów może być kwestionowany. Najwięcej wątpliwości budzi możliwość traktowania UE jako jednolitego aktora stosunków międzynarodowych. M. Sułek wyraźnie zaznacza, iż fakt ten musi być brany pod uwage przy ocenie zgromadzonych danych. Można również postawić pytanie o rozszerzenie analizy o inne państwa, jak np. często ostatnio analizowane wschodzące mocarstwa chociażby z grupy BRICS. Nie sposób jednak nie zauważyć, iż tego typu analizy zawsze zawierają sporą dozę arbitralności i zastosowane przez M. Sułka podejście można bez trudu zastosować do innych podmiotów.

Zasadnicza treść artykułu stanowi pomiar potęgi USA, UE i Chin przy pomocy różnych modeli i rankingów. Konkretnie, autor artykułu stosuje własną formułę pomiaru potęi państwa, matrycę strategiczną (opracowaną przez badaczy rosyjskich), wskaźniki potęgi miękkiej oraz wybrane rankingi międzynarodowe. Podsumowując wyniki wszystkich pomiarów M. Sułek dochodzi do wniosku, iż wszystkie trzy podmioty dysponują istotną i zrównoważoną potęgą. USA wyraźnie dominują pod względem militarnym, podczas gdy UE nie może być do końca traktowana jako jednolity aktor w stosunkach międzynarodowych. Bardzo ważnym wnioskiem jest ocena potęgi Chin. Jak zauważa autor omawianego artykułu: ,[...] jakość potęgi Chin jest o wiele niższa niż potęgi USA, co oznacza m.in., że potęga Chin ma charakter umiarkowanie czynny, a może wręcz bierny, podczas gdy potęga Ameryki ma charakter czynny" (Sułek, 2014: 346-347). Zdaniem M. Sułka w wielu współczesnych analizach potęga Chin jest zatem przeszacowana. Podsumowując te rozważania należy zauważyć, iż sposób, a nawet zasadność pomiaru potęgi państw budzi kontrowersje wśród badaczy. Wielu uważa, iż jest to zjawisko niemierzalne i próby odwzorowania go za pomocą metod ilościowych są z góry skazane na niepowodzenie. Naturalnie przy tego typu analizach zawsze można kwestionować dobór wskaźników jako arbitralny. Mimo to w opinii autora przeglądu, analizy takie są wartościowe dla nauki o bezpieczeństwie międzynarodowym, a artykuł M. Sułka stanowi interesujący wkład w debatę o zmianie międzynarodowego układu sił.

W kontekście analizy międzynarodowego układu sił i oceny potęgi poszczególnych państw interesujących wniosków dostarcza artykuł pt. International power dimensions of higher education in the age of knowledge autorstwa Anny Wojciuk opublikowany na łamach czasopisma „Stosunki Międzynarodowe”. Tekst ten dotyczy stosunkowo rzadko podejmowanego w nauce o stosunkach międzynarodowych aspektu, jakim jest rola szkolnictwa wyższego jako zasobu potęgi państwa, jak również środka wpływu na otoczenie międzynarodowe. A. Wojciuk podkreśla, iż jej badania są osadzone w podejściu realistycznym, co przejawia się w założeniu, iż państwa są zasadniczymi aktorami omawianych interakcji oraz, iż kierują się one dążeniem do utylitarnej maksymalizacji potęgi. Autorka omawianego artykułu zakłada, iż w obecnej fazie przejścia z gospodarki przemysłowej do opartej na wiedzy szkolnictwo wyższe stanowi istotne źródło potęgi państwa. Dotyczy to zarówno statycznego rozumienia potęgi (wiedza i szkolnictwo 
jako zasób), jak i bardziej relacyjnego podejścia (szkolnictwo wyższe jako narzędzie wpływu na otoczenie międzynarodowe).

Na podstawie przeprowadzonych przez siebie badań autorka omawianego tekstu zidentyfikowała trzy strategie przyjmowane przez państwa odnośnie szkolnictwa wyższego w kontekście potęgi. Pierwsza zakłada wykorzystanie współpracy w dziedzinie szkolnictwa wyższego jako źródła wpływów. Sprowadza się ona przede wszystkim do ułatwiania międzynarodowej wymiany studentów ze wzajemnym pożytkiem zarówno dla państwa przyjmującego studentów, jak i państwa ich pochodzenia. Jest to strategia stosowana przez mocarstwa w celu zwiększania soft power w stosunku do państw pochodzenia studentów. Druga strategia zakłada budowę narodowych zasobów i zdolności w obszarze szkolnictwa wyższego i wyróżnia się bardziej merkantylnym podejściem do przepływu osób i wiedzy. Jest ona przyjmowana głównie przez państwa rozwijające się, a szczególnie wschodzące potęgi, które dążą do budowy i rozwoju narodowych zdolności w tym obszarze. Trzecia strategia, występująca głównie w państwach anglosaskich o rozwiniętych i konkurencyjnych sektorach naukowych sprowadza się do traktowania szkolnictwa wyższego jako jednego z sektorów oferujących usługi na międzynarodowym rynku. Chociaż artykuł ten stanowi dopiero wstęp do szerszych badań i dyskusji nt. roli szkolnictwa wyższego i szerzej nauki we współczesnym międzynarodowym układzie sił to bez wątpienia w interesujący i trafny sposób zwraca uwagę na nowy i w dużej mierze jeszcze niezbadany aspekt stosunków międzynarodowych.

W kontekście nowych obszarów badawczych w studiach nad bezpieczeństwem, warto wspomnieć o publikacjach Łukasza Kamieńskiego dotyczących wykorzystania najnowszych osiągnięć biotechnologii dla potrzeb sił zbrojnych USA. W dwóch artykułach opublikowanych na łamach „Kwartalnika Bellona” (Nieuświadomiona percepcja, czyli neurobiologia na ustugach amerykańskiej armii oraz Profilowanie genetyczne zolnierzy. Fantastyka czy realny scenariusz?) autor ten prezentuje wycinkowo dwa zagadnienia będące elementem szerszego projektu badawczego dotyczącego militarnych zastosowań nowych technologii i ich potencjalnego wpływu na sposób prowadzenia wojny. W obu tekstach $€$. Kamieński prezentuje aktualne prace badawcze prowadzone w USA nad takimi zagadnieniami jak genetyczne profilowanie żołnierzy czy poprawianie świadomości sytuacyjnej żołnierzy na drodze wykorzystania osiagnięć neurobiologii celem stworzenia doskonalszych „interfejsów mózg-maszyna”. Warto zaznaczyć, iż technologie te wyszły już poza stadium koncepcyjne i coraz bliżej im do fazy wdrożeniowej. Chociaż oba artykuły mają w większym stopniu charakter opisowy, to jednak cały projekt badawczy (którego owocem jest również publikacja monograficzna) podnosi niezwykle doniosłe kwestie społecznych, prawnych, militarnych i etycznych konsekwencji rozwoju biotechnologii i jej adaptacji do potrzeb militarnych. Chociaż zdaje się, iż studia nad bezpieczeństwem wyszły już z fazy swoistego determinizmu technologicznego, który charakteryzował chociażby pierwsze prace nt. odstraszania nuklearnego, to jednak nie mogą one ignorować dokonujących się rewolucyjnych zmian w sposobach prowadzenia działań zbrojnych, zwłaszcza tych, które ingerują w ludzką biologię.

Podsumowując wyniki tego siłą rzeczy selektywnego i subiektywnego przeglądu polskiej prasy naukowej dotyczącej tematyki bezpieczeństwa międzynarodowego moż- 
na zwrócić uwagę na dominację tematyki związanej z szeroko pojętym bezpieczeństwem obszaru euroatlantyckiego. Nie może to dziwić biorąc pod uwagę przynależność naszego państwa to tego regionu, jak również doniosłe zmiany w międzynarodowym środowisku bezpieczeństwa, które w nim zachodzą. Naturalnie Polscy autorzy podejmują również tematykę dotyczącą innych regionów oraz zagadnień globalnych. Interesujący jest jednak brak tematyki Afgańskiej (w roku zakończenia misji ISAF). Wyjątkiem jest tu interesujący tekst Adriany Łukaszewicz o znaczeniu rynku narkotykowego dla afgańskiej gospodarki i państwa. Właściwie nieobecna jest problematyka afrykańska czy latynoamerykańska, a nie sposób zaprzeczyć, iż na tych obszarach toczą się ważne $\mathrm{i}$ interesujące procesy.

\section{Bibliografia}

Dzisiów-Szuszczykiewicz A. (2014), Bliskowschodnia ,zimna wojna” czyli saudyjsko-irańska rywalizacja w regionie w obliczu ,arabskiej wiosny”, „Bezpieczeństwo Narodowe”, nr 2.

Fryc M. (2014), „Doktryna Komorowskiego”- próba scharakteryzowania. Idea, zakres, priorytety, realizacja, „Bezpieczeństwo Narodowe”, $\mathrm{nr} 2$.

Kamieński Ł. (2014), Nieuświadomiona percepcja, czyli neurobiologia na ustugach amerykańskiej armii, „Kwartalnik Bellona”, nr 3.

Kamieński Ł. (2014), Profilowanie genetyczne żotnierzy. Fantastyka czy realny scenariusz?, „Kwartalnik Bellona", nr 4.

Koziej S., Pietrzak P. (2014), Szczyt NATO w Walii: uwarunkowania, rezultaty, wnioski dla Polski, „Bezpieczeństwo Narodowe”, nr 3.

Kuźniar R. (2014), Wzlot i upadek Europejskiej Polityki Bezpieczeństwa i Obrony, „Bezpieczeństwo Narodowe", nr 4.

Krivoushin I. (2014), France and Sub-Saharan Africa in the post-colonial era, „R/evolutions: Global Trends \& Regional Issues", nr 1, Vol. 2.

Łukaszewicz A. (2014), Znaczenie rynku narkotykowego dla gospodarki Afganistanu i jego wptyw na ksztalt państwa, „Stosunki Międzynarodowe”, nr 2, t. 50.

Madej M. (2014), NATO: zagończyk wraca do „pracy u podstaw”, „Rocznik Strategiczny 2013/14”.

Makowski A. (2014), O co my walczymy?, „Kwartalnik Bellona”, nr 3.

Michałek M. (2014), Przydatność kategorii systemu trybutarnego w analizie polityki zagranicznej Chin, „Stosunki Międzynarodowe”, nr 1, t. 49.

Michta A. (2014), NATO po 2014 roku - jakie priorytety?, „Bezpieczeństwo Narodowe”, nr 1.

Sułek M. (2014), USA, UE i Chiny - trzy bieguny w globalnym układzie sit, „Rocznik Strategiczny 2013/14".

Terlikowski M., Madej M. (2014), Wspólna Polityka Bezpieczeństwa i Obrony UE-przełom, którego (zgodnie z planem) nie byto, „Rocznik Strategiczny 2013/14”.

Wojciuk A. (2014), International power dimensions of higher education in the age of knowledge, „Stosunki Międzynarodowe”, nr 1, t. 49.

Zięba R. (2014), Międzynarodowe implikacje kryzysu ukraińskiego, „Stosunki Międzynarodowe”, nr 2, t. 50 . 


\title{
STRESZCZENIE
}

Artykuł stanowi subiektywny przegląd artykułów publikowanych w 2014 r. na łamach wybranych polskich czasopism naukowych z obszaru studiów nad bezpieczeństwem międzynarodowym („Kwartalnik Bellona”, „Bezpieczeństwo Narodowe”, „Rocznik Strategiczny” oraz „Stosunki Międzynarodowe”). Autor dokonał wyboru tekstów dotyczących najczęściej poruszanych tematów (jak np. konflikt ukraiński, ewolucja NATO oraz WPBiO), jak również prezentujących ciekawe i innowacyjne stanowiska badawcze (np. szkolnictwo wyższe jako zasób potęgi państwa czy militarne zastosowania biotechnologii). Prezentacja tez autorów omawianych tekstów została dodatkowo opatrzona komentarzem naukowym.

\section{POLISH STRATEGIC ANALYSES - 2014 REVIEW}

\begin{abstract}
The article constitutes a subjective review of articles published in 2014 on the pages of selected Polish academic journals dealing with International Security Studies („Kwartalnik Bellona”, „Bezpieczeństwo Narodowe”, „Rocznik Strategiczny” and „Stosunki Międzynarodowe”). The author has selected texts dealing with most popular topics (e.g. Ukrainian conflict, evolution of NATO and CSDP), as well those presenting interesting and innovative research propositions (e.g. higher education as a resource for state power or military applications o biotechnology). Presentation of thesis put forward by authors of selected articles is accompanied by scientific comments.
\end{abstract}


